HEPATITIS

\title{
Hepatitis B reactivation after withdrawal of pre- emptive lamivudine in patients with haematological malignancy on completion of cytotoxic chemotherapy
}

\author{
C-K Hui, W W W Cheung, W-Y Au, A K W Lie, H-Y Zhang, Y-H Yueng, B C Y Wong, \\ N Leung, Y-L Kwong, R liang, G K K Lau
}

See end of article for authors' affiliations

Correspondence to: Dr C-K Hui, Department of Medicine, University of Hong Kong, Queen Mary Hospital, 102 Pokfulam $\mathrm{Rd}$, Hong Kong SAR, China;

ckhvi23@gmail.com

Revised version received 23 May 2005

Accepted for publication 8 June 2005

Published online first

14 July 2005

Background: The hepatic outcome of hepatitis B surface antigen ( $\mathrm{HBs} A g)$ positive patients undergoing chemotherapy after withdrawal of pre-emptive lamivudine is unknown.

Aims: To examine the occurrence of hepatitis B virus (HBV) reactivation after withdrawal of pre-emptive lamivudine.

Methods: Pre-emptive lamivudine was started one week before initiation of chemotherapy in 46 consecutive $\mathrm{HBsAg}$ positive patients and continued for the entire duration of chemotherapy. Pre-emptive lamivudine was stopped at a median 3.1 (range 3.0-3.4) months after completion of chemotherapy. Patients were longitudinally followed up after withdrawal of pre-emptive lamivudine.

Results: Median time of follow up after withdrawal of lamivudine was 25.7 (range 5.7-75.7) months. Eleven of the 46 patients (23.9\%) developed HBV reactivation after withdrawal of pre-emptive lamivudine. Eight of the 16 patients with high pre-chemotherapy HBV DNA $\left(\geqslant 10^{4}\right.$ copies $/ \mathrm{ml}$ ) compared with three of the 30 patients with low pre-chemotherapy HBV DNA $\left(<10^{4}\right.$ copies/ml) developed HBV reactivation $(50.0 \% \vee 10.0 \%$, respectively; $p<0.001)$. Hepatitis $B$ e antigen positive patients were also more likely to develop HBV reactivation (5/11 (45.5\%) $\vee 6 / 35(17.1 \%)$, respectively; $p=0.041)$. A high prechemotherapy HBV DNA ( $\geqslant 10^{4}$ copies $/ \mathrm{ml}$ ) was the most important risk factor for HBV reactivation after withdrawal of pre-emptive lamivudine on Cox proportional hazards analysis (relative risk 16.13, 195\% confidence interval 2.99-87.01; $p=0.001$ ).

Conclusions: HBV reactivation is more likely to occur in patients with high pre-chemotherapy HBV DNA after withdrawal of pre-emptive lamivudine. A more prolonged course of antiviral therapy may be necessary in these patients after completion of chemotherapy in order to reduce post-chemotherapy HBV reactivation.

$\mathrm{H}$ epatitis due to hepatitis B virus (HBV) reactivation is a serious cause of liver related morbidity and mortality in hepatitis B surface antigen ( $\mathrm{HBsAg})$ positive patients undergoing cytotoxic or immunosuppressive therapy..$^{12}$ Liver damage due to $\mathrm{HBV}$ reactivation is a two stage process. Initially, during intense cytotoxic or immunosuppressive therapy, there is an increase in viral replication, as reflected by an increase in serum levels of HBV DNA, hepatitis B e antigen (HBeAg), and HBV DNA polymerase, resulting in widespread infection of hepatocytes. Restoration of immune function due to withdrawal of cytotoxic or immunosuppressive therapy will then result in a rapid immune mediated destruction of HBV infected hepatocytes. This destruction of HBV infected hepatocytes can manifest as hepatitis, hepatic failure, and even death. ${ }^{2-4}$

Although initial reports of $\mathrm{HBV}$ reactivation involved mainly patients with haematological malignancies, it has also been reported in patients with solid tumours. ${ }^{35-9}$ Reactivation of HBV replication with decompensation has been reported in $20-50 \%$ of chronic HBV patients undergoing cytotoxic chemotherapy. ${ }^{310}$ With the increasing incidence of neoplastic diseases and more widespread use of cytotoxic chemotherapy, the incidence of HBV reactivation is likely to rise further in HBV endemic areas and in migrants from HBV endemic areas. ${ }^{11}$ This has led to the recent recommendation that patients undergoing cytotoxic chemotherapy should be screened for HBsAg before initiation of chemotherapy. ${ }^{12}$
As HBV reactivation due to cytotoxic or immunosuppressive therapy is related to the host immune response to enhanced HBV replication, antiviral agents such as lamivudine and famciclovir have been used to decrease the risk of $\mathrm{HBV}$ reactivation in patients receiving immunosuppressive therapy ${ }^{13-18}$ However, despite the use of nucleoside analogues at the time of clinical hepatitis, hepatic failure and mortality still occurred. This is likely to be due to the late institution of nucleoside analogues when the immune mediated damage of the liver has already been established. ${ }^{19}$ Hence it is accepted that nucleoside analogues should be administered preemptively before the onset of clinical hepatitis due to HBV virological reactivation. ${ }^{19-21}$

The availability of data on the safety and efficacy of lamivudine as pre-emptive therapy for patients undergoing cytotoxic or immunosuppressive therapy has led to a consensus recommendation that all patients with chronic HBV infection should be given a short course of lamivudine while receiving cytotoxic or immunosuppressive therapy as prophylaxis against reactivation of $\mathrm{HBV} .{ }^{12}{ }^{22}$ But, as prolonged lamivudine therapy is associated with an increased likelihood of developing lamivudine resistant mutants, most

Abbreviations: $H B V$, hepatitis $B$ virus; $H B s A g$, hepatitis $B$ surface antigen; $\mathrm{HBeAg}$, hepatitis $B$ e antigen; anti-HBs, hepatitis $B$ surface antibody; anti-HBe, hepatitis $B$ e antibody; RR, relative risk; $A L T$, alanine aminotransaminase; $\mathrm{PCR}$, polymerase chain reaction 
cancer centres would aim at discontinuing or withdrawing pre-emptive lamivudine as soon as possible in order to limit the duration of antiviral therapy. ${ }^{20-26}$ However, at the moment there is no available consensus on the optimal duration of lamivudine therapy. This is mostly due to lack of data on the occurrence of hepatic flares after the withdrawal of preemptive antiviral therapy in these patients.

The current recommendation is for prophylactic lamivudine to be started one week before and continued for at least six weeks after the end of chemotherapy in order to reduce the frequency and severity of HBV reactivation. ${ }^{12}$ Based on reported series, continuation of lamivudine for a variable period of 1-6 months after completion of chemotherapy has been shown to be equally effective in reducing HBV reactivation. ${ }^{13} 16172728$ However, the duration of pre-emptive lamivudine in these studies is arbitrary and a predetermined set of criteria for the withdrawal of lamivudine after completion of chemotherapy is not employed.

As HBV reactivation after cytotoxic or immunosuppressive therapy is usually accompanied by an upsurge of white cell counts from the nadir, our centre has adopted a protocol of only withdrawing lamivudine once the total white cell count has normalised $\left(>4.0 \times 10^{9} / 1\right)$ and at least three months after completion of chemotherapy. ${ }^{21}$ The concept of this protocol or approach is to cover the entire period when the host interaction with HBV has been disturbed as a result of the cytotoxic or immunosuppressive therapy. This way, we would only be withdrawing lamivudine after recovery from the effects of cytotoxic or immunosuppressive therapy and at a time when the host's immune system has recovered sufficiently to the pre-chemotherapy state.

In our present study, we examined the occurrence of hepatic flares after withdrawal of pre-emptive lamivudine, and determined what factors are associated with hepatic flares after withdrawal of pre-emptive lamivudine.

\section{PATIENTS AND METHODS}

\section{Patients}

From 1999 to December 2004, 1093 consecutive patients were treated with intravenous cytotoxic chemotherapy for

Table 1 Pre-chemotherapy clinical and virological characteristics of the 46 patients included in the study

\begin{tabular}{lc}
\hline Characteristic & \\
\hline Sex (M:F) & $23: 23$ \\
Age (y) & 46 (21-78) \\
ALT (U/I) & 27 (10-108) \\
Elevated ALT & 4 \\
Yes & 42 \\
No & \\
HBV DNA $\geqslant 10^{4}$ copies/ml & 16 \\
Yes & 30 \\
No & \\
HBeAg & 11 \\
Positive & 35 \\
Negative & \\
Anti-HBe & 35 \\
Positive & 11 \\
Negative & 33 \\
Diagnosis & 2 \\
Non-Hodgkin's lymphoma & 8 \\
Hodgkin's lymphoma & 3 \\
Acute myeloid leukaemia & \\
Multiple myeloma & 36 \\
Chemotherapy regimen & 35 \\
Steroid containing chemotherapy & 30 \\
Anthracycline containing chemotherapy & \\
Vinca alkaloid containing chemotherapy & \\
\hline Continuous variables expressed in median (range). & \\
ALT, alanine aminotransaminase (normal range 13 & \\
HBeAg, hepatitis B e antigen; anti-HBe, hepatitis B e antibody. \\
\hline
\end{tabular}

haematological malignancy at the Haematology and Oncology Unit, University Department of Medicine, Queen Mary Hospital, Hong Kong SAR, China. All patients were screened for HBsAg, hepatitis B surface antibody (anti-HBs) (enzyme-linked immunosorbent assay II; Abbott Laboratories, Chicago, Illinois, USA), human immunodeficiency virus antibody (Abbott Laboratories), and hepatitis C virus antibody (Ortho Diagnostics System, Raritan, New Jersey, USA). Further testing for HBeAg, hepatitis B e antibody (anti-HBe; Abbott Laboratories), and serum HBV DNA was performed on all HBsAg positive patients. Serum HBV DNA was quantified by real time polymerase chain reaction (PCR) using the DyNAmo HS SYBR Green qPCR kit (Finnzymes Oy, Finland), as previously described by our group. ${ }^{29}$ The linear quantification range of our assay is $10^{2}-$ $10^{8}$ copies $/ \mathrm{ml}$.

All HBsAg positive patients were assessed by an experienced hepatologist (GKKL) before initiation of chemotherapy. None of the HBsAg positive patients had clinical evidence of decompensated cirrhosis (ankle oedema, ascites, jaundice, hepatic encephalopathy), and their albumin, bilirubin, and prothrombin time were all within the normal range.

All HBsAg positive patients were managed by a single hepatologist (GKKL) according to a standardised protocol. Pre-emptive lamivudine was started one week before initiation of chemotherapy. Pre-emptive lamivudine was continued throughout the entire period of chemotherapy and was discontinued at least three months after completion of chemotherapy and when the total white cell count had normalised (normal range 4.0-11.0 $\times 10^{9} / 1$ ).

All patients were prospectively followed up every two weeks while on lamivudine or chemotherapy. After withdrawal of lamivudine, patients were prospectively followed up every two weeks for the first three months and then monthly until the time of analysis (March 2005) or death. At each follow up visit, the clinical status of the recipients was recorded and blood was tested for liver biochemistry (serum alanine aminotransaminase (ALT), aspartate aminotransaminase, bilirubin, and albumin). HBsAg, HBeAg, anti-HBs, and anti-HBe, and serum HBV DNA were also tested on every visit.

Patients developing hepatic failure were tested for lamivudine resistant mutants by determination of HBV polymerase gene by direct sequencing, as previously described. ${ }^{15}$

\section{Definition of hepatic events}

HBV related hepatitis during chemotherapy was diagnosed in the presence of a more than threefold elevation in serum ALT levels on two consecutive tests five days apart, accompanied by an elevation in serum HBV DNA to more than 10 times that of the pre-exacerbation baseline in a patient who remained HBV DNA positive or if serum HBV DNA switched from negative to positive.

Table 2 Median time from initiation of pre-emptive lamivudine to withdrawal of lamivudine in conjunction with chemotherapy

\begin{tabular}{ll}
\hline & $\begin{array}{l}\text { Duration (months) } \\
\text { (median (range)) }\end{array}$ \\
\hline $\begin{array}{l}\text { Duration of lamivudine before chemotherapy } \\
\text { Duration of lamivudine during chemotherapy }\end{array}$ & $1.0(0.9-2.0) \mathrm{wk}$ \\
$\begin{array}{l}\text { Time between end of chemotherapy and } \\
\text { withdrawal of lamivudine }\end{array}$ & $3.1(3.0-27.6)$ \\
$\begin{array}{l}\text { Total duration of pre-emptive lamivudine } \\
\text { Tol }\end{array}$ & $9.2(6.2-31.5)$ \\
\hline
\end{tabular}




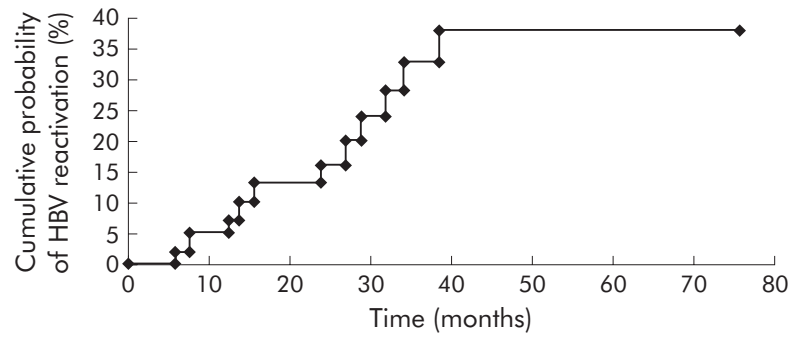

Figure 1 Cumulative probability of hepatitis B virus (HBV) reactivation after withdrawal of pre-emptive lamivudine therapy.

HBV reactivation after lamivudine withdrawal was defined as elevation of serum ALT levels above the upper limit of normal on two consecutive determinations at least five days apart accompanied by a serum HBV DNA of $\geqslant 10^{5}$ copies $/ \mathrm{ml}$ in $\mathrm{HBeAg}$ positive patients or elevated serum ALT levels on two consecutive determinations five days apart accompanied by a serum HBV DNA of $\geqslant 10^{4}$ copies/ml in HBeAg negative patients. ${ }^{22}$ Hepatic failure was defined as the presence of hepatic encephalopathy and deranged blood coagulation (prothrombin time exceeding 10 seconds of control).

This study was approved by the Institutional Review Board of the Queen Mary Hospital, Hong Kong SAR, China. Informed consent was obtained from all patients for longitudinal follow up.

\section{Statistical analysis}

All statistical analyses were performed using the Statistical Program for Social Sciences (SPSS 12.5 for windows; SPSS Inc., Chicago, Illinois, USA). The Mann-Whitney U test was used for comparing two continuous variables and the $\chi^{2}$ test with Yates' correction for continuity or Fisher's exact test for comparing two categorical variables. The primary outcome measure was occurrence of HBV reactivation after withdrawal of lamivudine. The secondary outcome measure was to determine the occurrence of hepatic failure due to HBV reactivation after withdrawal of lamivudine and to determine the variables associated with HBV reactivation and hepatic
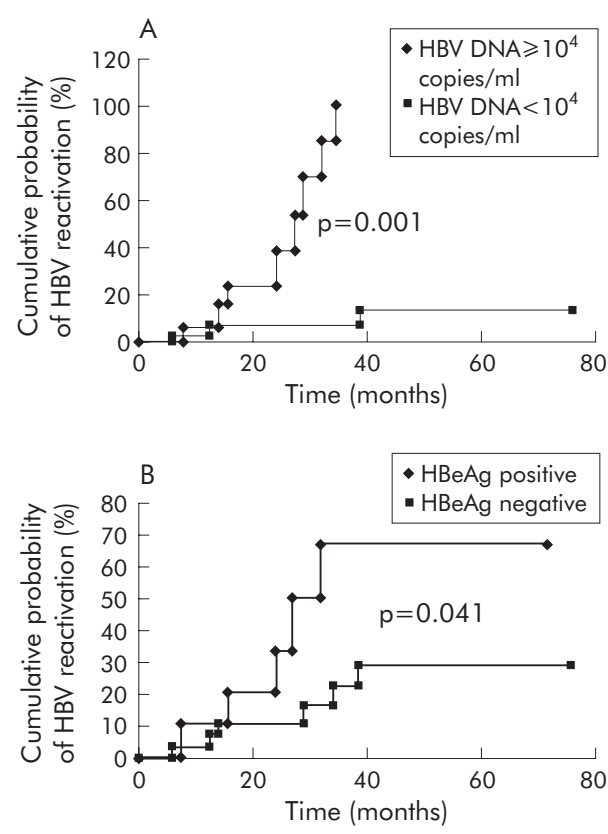

Figure 2 Cumulative probability of hepatitis $B$ virus (HBV) reactivation after withdrawal of lamivudine according to (A) HBV DNA status and (B) hepatitis $B$ e antigen $(\mathrm{HBeAg})$ status.

failure after lamivudine withdrawal. The Kaplan-Meier method was employed for calculation of the cumulative probability of HBV reactivation. A Cox's proportional hazards model was used to estimate the relative risk (RR) of HBV reactivation after withdrawal of lamivudine and hepatic failure associated with HBV DNA levels of $\geqslant 10^{4}$ copies $/ \mathrm{ml}$, positive HBeAg, and abnormal serum ALT levels prechemotherapy. The $95 \%$ confidence interval (CI) for the RR was also calculated. Continuous variables were expressed as median (range). All statistical analyses were performed on an intention to treat basis. Statistical significance was defined as $\mathrm{p}<0.05$ (two tailed).

Table 3 Characteristics of patients with and without hepatitis B virus (HBV) reactivation after withdrawal of lamivudine

\begin{tabular}{|c|c|c|c|}
\hline Characteristic & $\begin{array}{l}\text { Patients with HBV } \\
\text { reactivation after } \\
\text { withdrawal of } \\
\text { lamivudine }(n=11)\end{array}$ & $\begin{array}{l}\text { Patients without HBV } \\
\text { reactivation after } \\
\text { withdrawal of } \\
\text { lamivudine }(n=35)\end{array}$ & p Value \\
\hline $\operatorname{Sex}(M: F)$ & $7: 4$ & $16: 19$ & 0.491 \\
\hline Age (y) & $51(24-71)$ & $44(21-78)$ & 0.787 \\
\hline ALT (U/I) & $21(12-55)$ & $28(10-108)$ & 0.523 \\
\hline Elevated ALT & & & 1.000 \\
\hline Yes & 1 & 3 & \\
\hline No & 10 & 32 & \\
\hline HBV DNA $\geqslant 10^{4}$ copies $/ \mathrm{ml}$ & & & 0.004 \\
\hline Yes & 8 & 8 & \\
\hline No & 3 & 27 & \\
\hline $\mathrm{HBeAg}$ & & & 0.055 \\
\hline Positive & 5 & 6 & \\
\hline Negative & 6 & 29 & \\
\hline Diagnosis & & & 0.689 \\
\hline Non-Hodgkin's lymphoma & 8 & 25 & \\
\hline Hodgkin's lymphoma & 1 & 1 & \\
\hline Acute myeloid leukaemia & 1 & 7 & \\
\hline Multiple myeloma & 1 & 2 & \\
\hline Duration of lamivudine (months) & $11.8(7.3-29.3)$ & $7.8(7.2-31.5)$ & 0.634 \\
\hline
\end{tabular}

Continuous variables expressed in median (range).

ALT, alanine aminotransaminase (normal range 13-51 U/I).

$\mathrm{HBeAg}$, hepatitis $\mathrm{B}$ e antigen. 
Table 4 Adjusted relative risk of hepatitis B virus (HBV) reactivation after withdrawal of lamivudine according to various risk factors

\begin{tabular}{lll}
\hline Variable & $\begin{array}{l}\text { Adjusted relative risk } \\
(95 \% \mathrm{Cl})\end{array}$ & p Value \\
\hline $\begin{array}{l}\text { HBV DNA } \geqslant 10^{4} \text { copies/ml pre-chemotherapy } \\
\text { Yes }\end{array}$ & $16.13(2.99-87.01)$ & 0.001 \\
$\quad$ No & 1 & \\
HBeAg pre-chemotherapy & $1.39(0.38-5.11)$ & 0.621 \\
$\quad \begin{array}{l}\text { Positive } \\
\quad \text { Negative }\end{array}$ & 1 & \\
$\begin{array}{l}\text { Abnormal serum ALT pre-chemotherapy: } \\
\text { Yes }\end{array}$ & $1.596(0.07-5.04)$ & 0.635 \\
No & 1 & \\
\hline
\end{tabular}

$\mathrm{HBeAg}$, hepatitis $\mathrm{B}$ e antigen; $\mathrm{Cl}$, confidence interval.

$\mathrm{ALT}$, alanine aminotransaminase (normal range 13-51 U/I).

\section{RESULTS}

A total of 128 of 1093 patients (11.7\%) were HBsAg positive. Of these $128 \mathrm{HBsAg}$ positive patients, 82 were excluded from analysis for the following reasons: $41(32.0 \%)$ patients had haematopoietic stem cell transplantation after clinical remission was achieved, 30 (23.4\%) had already been included into a previous study, ${ }^{21}$ nine $(7.0 \%)$ died of disease progression and were still on lamivudine at the time of fatality, and two (1.6\%) developed YMDD resistance while on lamivudine and
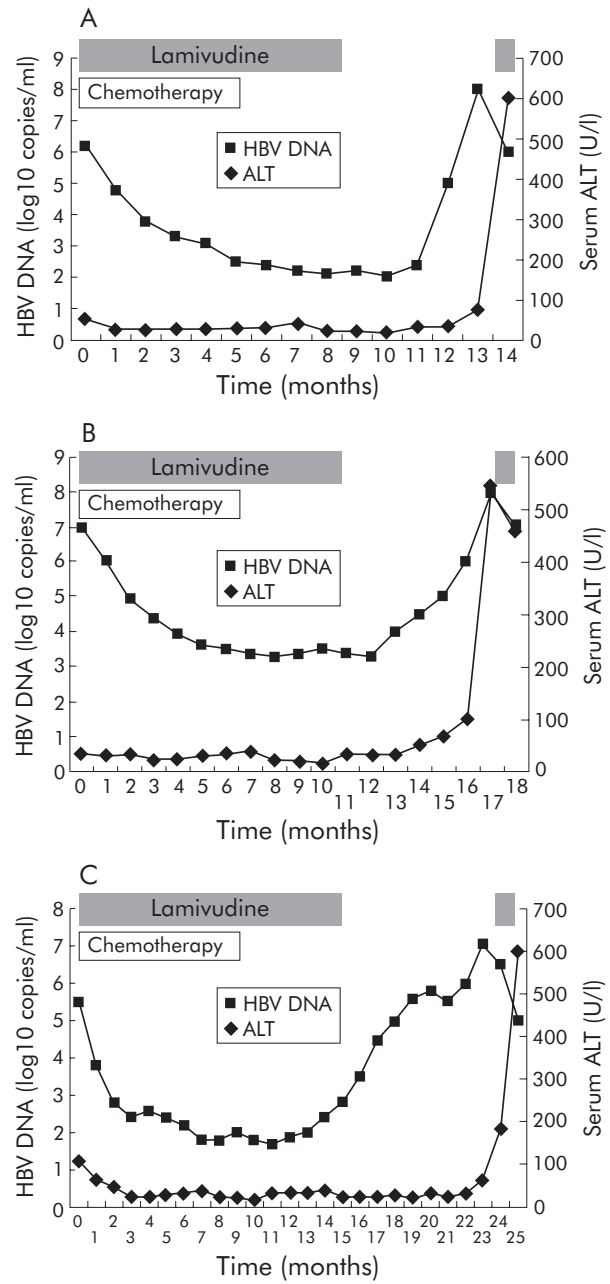

Figure 3 Serum hepatitis $B$ virus (HBV) DNA and alanine aminotransaminase (ALT) levels in three (A-C) patients with hepatic failure due to HBV reactivation after withdrawal of lamivudine. The period of lamivudine treatment is indicated. were commenced on adefovir dipivoxil in addition to lamivudine. None of these 46 patients had stigmata of chronic liver disease or evidence of liver cirrhosis before chemotherapy. The remaining 46 of these 128 patients $(35.9 \%)$ were included in the study. Demographic data of these 46 patients are shown in table 1.

None of these 46 patients developed HBV related hepatitis during the course of chemotherapy. Median duration of preemptive lamivudine in conjunction with chemotherapy is shown in table 2 .

\section{HBV reactivation after withdrawal of pre-emptive lamivudine}

Median follow up time after withdrawal of lamivudine to the time of analysis in these 46 patients was 25.7 (range 5.775.7) months. At the time of withdrawal, all patients (100\%) had a serum HBV DNA level of $<10^{4}$ copies $/ \mathrm{ml}$.

Eleven of the 46 patients (23.9\%) developed HBV reactivation after withdrawal of lamivudine (fig 1). The cumulative probability rates of HBV reactivation after lamivudine withdrawal at 3, 6, 12, 18, 24, and 36 months were $0 \%, 2 \%, 5 \%$, $13 \%, 16 \%$, and 33\%, respectively (fig 1). Lamivudine was resumed in all 11 patients who developed HBV reactivation. Baseline characteristics of patients with and without HBV reactivation after withdrawal of lamivudine are shown in table 3.

Factors predictive of HBV reactivation after withdrawal of lamivudine were serum HBV DNA $\geqslant 10^{4}$ copies $/ \mathrm{ml}$ before chemotherapy (8/16 patients $(50.0 \%) v 3 / 30(10.0 \%)$ patients, respectively; $\mathrm{p}<0.001$ on log rank) (fig $2 \mathrm{~A}$ ) and a positive HBeAg before chemotherapy (5/11 patients (45.5\%) v 6/35 ( $17.1 \%$ ) patients, respectively; $\mathrm{p}=0.041$ on log rank) (fig $2 \mathrm{~B}$ ).

When multivariate Cox regression analysis was used to assess HBV reactivation after withdrawal of pre-emptive lamivudine, a serum HBV DNA of $\geqslant 10^{4}$ copies $/ \mathrm{ml}$ before chemotherapy was the only independent factor in predicting HBV reactivation after withdrawal of pre-emptive lamivudine (RR 16.13 (95\%CI 2.99-87.01); $\mathrm{p}=0.001$ ) (table 4).

\section{Hepatic failure due to $\mathrm{HBV}$ reactivation after withdrawal of lamivudine}

Three of 11 patients $(27.3 \%)$ with HBV reactivation after withdrawal of lamivudine developed fulminant hepatic failure (fig 3). None of these three patients with hepatic failure had lamivudine resistant mutants. The characteristics of these three patients are shown in table 5 .

One of these 11 patients $(9.1 \%)$ died from bleeding oesophageal varices and hepatic encephalopathy. Ten of 11 patients $(90.9 \%)$ with HBV reactivation recovered with lamivudine therapy. All 10 patients were still alive at the time of analysis. 
Table 5 Clinical characteristics of the three patients with hepatic failure due to hepatitis B virus (HBV) reactivation after withdrawal of lamivudine

\begin{tabular}{|c|c|c|c|c|c|c|c|c|c|c|c|}
\hline \multirow[b]{2}{*}{$\begin{array}{l}\text { Patient } \\
\text { No }\end{array}$} & \multirow[b]{2}{*}{$\begin{array}{l}\text { Age } \\
\text { (y) }\end{array}$} & \multirow[b]{2}{*}{ Sex } & \multicolumn{3}{|c|}{$\begin{array}{l}\text { HBV status before } \\
\text { chemotherapy }\end{array}$} & \multirow{2}{*}{$\begin{array}{l}\text { Time of HBV } \\
\text { reactivation } \\
\text { after initiation } \\
\text { of chemotherapy }\end{array}$} & \multirow{2}{*}{$\begin{array}{l}\text { Time of HBV } \\
\text { reactivation } \\
\text { after lamivudine } \\
\text { withdrawal }\end{array}$} & \multirow{2}{*}{$\begin{array}{l}\text { HBV DNA } \\
>10^{4} \text { copies } / \mathrm{ml} \\
\text { before } \\
\text { chemotherapy }\end{array}$} & \multirow{2}{*}{$\begin{array}{l}\text { Elevated ALT } \\
\text { before } \\
\text { chemotherapy }\end{array}$} & \multirow{2}{*}{$\begin{array}{l}\text { Peak prothrombin } \\
\text { time during } \\
\text { hepatic failure } \\
\text { (s) }\end{array}$} & \multirow{2}{*}{ Outcome } \\
\hline & & & $\mathrm{HBsAg}$ & $\mathrm{HBeAg}$ & $\begin{array}{l}\text { Anti- } \\
\mathrm{HBe}\end{array}$ & & & & & & \\
\hline 1 & 51 & $M$ & + & + & - & 16.0 & 7.6 & Yes & No & 68.1 & Died \\
\hline 2 & 25 & $M$ & + & + & - & 17.8 & 5.8 & Yes & No & 23.4 & Recovered \\
\hline 3 & 57 & $\mathrm{~F}$ & + & - & + & 24.7 & 13.8 & Yes & Yes & 28.2 & Recovered \\
\hline
\end{tabular}

$H B V$, hepatitis B virus; $H B s A g$, hepatitis B surface antigen; $H B e A g$, hepatitis $B$ e antigen; anti-HBe, hepatitis $B$ e antibody.

ALT, alanine aminotransaminase (normal range 13-51 U/l).

Hepatic failure was higher in patients with a serum HBV DNA of $\geqslant 10^{4}$ copies/ml before chemotherapy (3/16 (18.8\%) patients $v 0 / 30(0 \%)$ patients, respectively; $p=0.005$ on $\log$ rank). Two of $11 \mathrm{HBeAg}$ positive patients compared with one of $35 \mathrm{HBeAg}$ negative patients developed hepatic failure after withdrawal of lamivudine $(18.2 \% \quad v 2.9 \%$, respectively; $p=0.069$ on log rank). One of four patients with elevated serum ALT levels before chemotherapy compared with two of 42 patients without elevated serum ALT levels before chemotherapy developed hepatic failure after withdrawal of lamivudine ( $25.0 \% \vee 4.8 \%$, respectively; $\mathrm{p}=0.068$ on log rank).

The relative risk of developing hepatic failure after withdrawal of lamivudine was higher in patients with serum HBV DNA of $\geqslant 10^{4}$ copies $/ \mathrm{ml}$ before chemotherapy and in patients with positive HBeAg before chemotherapy (table 6).

\section{HBV serology}

None of the $11 \mathrm{HBeAg}$ positive $(0 \%)$ patients lost $\mathrm{HBeAg}$ while none of the 35 anti-HBe positive (0\%) patients developed HBeAg reversion after withdrawal of lamivudine.

\section{DISCUSSION}

Nucleoside analogues such as lamivudine or adefovir dipivoxil are now available for the treatment of hepatitis due to HBV reactivation in HBsAg positive subjects undergoing intense chemotherapy. With the results of recent studies, it is now generally accepted that early rather than deferred pre-emptive therapy with these antiviral agents should be adopted for HBsAg lymphoma patients undergoing intense chemotherapy to reduce post-chemotherapy HBV related morbidity and mortality. ${ }^{21}{ }^{30}$ However, the optimal duration of lamivudine administration has not yet been defined. An additional 1-6 months of administration of lamivudine after completion of chemotherapy has been recommended by some studies. ${ }^{13} 16172728$ Nevertheless, prolonged use of lamivudine cannot guarantee its clinical benefit due to the emergence of lamivudine resistant strains in $10-30 \%$ after one year of therapy. ${ }^{31}$ On the other hand, if the duration of lamivudine therapy is too short, there is a risk that the antiviral prophylaxis may not be adequate.

One of the major concerns with the use of lamivudine has been the occurrence of withdrawal hepatic flares on stopping lamivudine. ${ }^{32}$ A few studies have reported on follow up of patients, with pre-emptive lamivudine being withdrawn 1-6 months after completion of chemotherapy. One reported no incidence of post-lamivudine hepatitis flares in its three cases, ${ }^{27}$ another had one case of hepatic flare among 20 patients, ${ }^{28}$ while the third only reported hepatic flares in four of their 65 patients. ${ }^{20}$ Hepatic flares in these studies were all reported to be self limiting. However, the follow up period after withdrawal of lamivudine was short and limited to approximately 8-12 weeks after withdrawal of pre-emptive lamivudine. One recent publication however reported delayed $\mathrm{HBV}$ reactivation in four HBsAg positive lymphoma patients at 6-8 months after withdrawal of lamivudine. ${ }^{30}$ Furthermore, there has been report on cases of hepatic failure resulting in fatality after withdrawal of lamivudine in immunocompetent patients with chronic HBV. ${ }^{33}$

In this study, we have longitudinally followed up a cohort of patients on pre-emptive lamivudine for a median of 25.7 (range 6-75) months. All patients had their pre-emptive lamivudine withdrawn under the same set of criteria. At the time of analysis, the cumulative probability of HBV reactivation 36 months after withdrawal of lamivudine was 33\%. The occurrence of hepatic flares due to HBV reactivation in this series was not as benign or as self limiting as previously reported..$^{20}$ In fact, three patients developed hepatic failure, with one fatality. The three cases of hepatic failure developed within 13 months of lamivudine withdrawal. None of these three patients with hepatic failure had lamivudine resistant mutants, detected by direct PCR sequencing. Thus patients should be monitored closely for a more prolonged period of time as no patient developed HBV reactivation within the first three months after lamivudine withdrawal (fig 1).

A serum HBV DNA level of $\geqslant 10^{4}$ copies $/ \mathrm{ml}$ before chemotherapy is an independent risk factor for the

\begin{tabular}{|c|c|c|}
\hline Variable & $\begin{array}{l}\text { Adjusted relative risk } \\
(95 \% \mathrm{Cl})\end{array}$ & p Value \\
\hline $\begin{array}{l}\text { HBV DNA } \geqslant 10^{4} \text { copies } / \mathrm{ml} \text { pre-chemotherapy } \\
\text { Yes } \\
\text { No }\end{array}$ & $\begin{array}{c}17.82(0.56-35.78) \\
1\end{array}$ & 0.345 \\
\hline $\begin{array}{l}\text { HBeAg pre-chemotherapy: } \\
\text { Positive } \\
\text { Negative }\end{array}$ & $1.85(0.17-20.53)$ & 0.616 \\
\hline $\begin{array}{l}\text { Elevated serum ALT pre-chemotherapy: } \\
\text { Yes } \\
\text { No }\end{array}$ & $1.49(0.13-16.87)$ & 0.746 \\
\hline
\end{tabular}

$\mathrm{HBeAg}$, hepatitis B e antigen; $\mathrm{Cl}$, confidence interval.

$\mathrm{ALT}$, alanine aminotransaminase (normal range 13-51 U/I). 
development of HBV reactivation after withdrawal of preemptive lamivudine. Withdrawal of lamivudine would result in a "rebound" and resurgence of viral replication. ${ }^{32}$ This "rebound" can result in HBV DNA returning to its prechemotherapy level or even higher, as shown in fig 3, and is in keeping with the observation made in another study. ${ }^{30}$ This explains why patients with a higher pre-chemotherapy HBV DNA have a higher risk of developing HBV reactivation or even hepatic failure after withdrawal of lamivudine.

In this study, HBeAg positive patients had a higher risk of developing HBV reactivation after withdrawal of pre-emptive lamivudine. This is probably because HBeAg positive patients had a higher HBV DNA level despite a normal serum ALT level (the immune tolerant phase). ${ }^{42}$ Furthermore, patients in the immune tolerant phase are also less likely to develop HBeAg seroconversion despite lamivudine, explaining why none of the 11 HBeAg positive patients in this study developed HBeAg seroconversion while on lamivudine. ${ }^{34}$

Therefore, patients with a high pre-chemotherapy serum HBV DNA might need a prolonged course of lamivudine in order to maintain remission of HBV. HBeAg positive patients may even require HBeAg seroconversion before pre-emptive lamivudine can be safely withdrawn in order to achieve a more prolonged clinical benefit. ${ }^{35} \mathrm{HBeAg}$ negative patients with high serum HBV DNA may also require prolonged therapy with lamivudine as it has been shown that a sustained response can be achieved in HBeAg negative immunocompetent patients after a two year course of lamivudine therapy. ${ }^{36}$

However, this prolonged course of lamivudine in HBeAg positive and negative patients will increase the risk of developing lamivudine resistant mutants. The fact that lamivudine resistant mutants can be associated with rapid clinical deterioration after transplantation has raised additional concerns about prolonged lamivudine therapy in immunocompromised patients. ${ }^{37}{ }^{38}$ One way to overcome this problem is by using alternative nucleoside analogues that have a better resistance profile such as adefovir dipivoxil or entecavir. Recently, it has been shown that entecavir has stronger antiviral activity compared with lamivudine and can result in more profound suppression of viral replication. It also has a better resistance profile with no evidence of genotypic resistance in nucleoside analogue naïve patients after 48 weeks of therapy. ${ }^{39}$ Therefore, further clinical trials with these agents or combination regimens with at least additive or preferably synergistic effects as pre-emptive therapy are warranted. ${ }^{40}$

One of the limitations of this study was the absence of a liver biopsy before commencement of lamivudine or chemotherapy. As Hong Kong is an endemic area for HBV infection, the most common mode of HBV infection is perinatal transmission. ${ }^{41}$ Thus many of the HBsAg positive patients in this study are likely to have been infected for four to five decades before developing haematological malignancy. As the baseline serum ALT levels of HBsAg positive patients are mostly within the normal range, it is unlikely that these patients have severe hepatic necroinflammation. ${ }^{42}$ On the other hand, it is possible that some of these patients had a more advanced stage of fibrosis at presentation, accounting for the oesophageal varices in one of the patients. This would be better characterised if baseline liver biopsy for these patients were available. However, it would be difficult to justify such a procedure in high risk patients with no specific clinical indication, such as derangement of liver function tests.

Finally, based on our experience and the currently available data, we would recommend that all patients undergoing intense cytotoxic chemotherapy be screened for HBsAg. HBsAg positive patients should be started on preemptive lamivudine one week before initiation of chemotherapy, especially those at a higher risk of developing HBV reactivation, those receiving steroid containing chemotherapy or haematopoietic stem cell transplantation, and those with a high pre-chemotherapy serum HBV DNA, high intrahepatic cccDNA, and HBeAg positivity. ${ }^{43-46}$ They should be closely monitored every four weeks while on chemotherapy for breakthrough hepatitis and HBV viral resistance. Pre-emptive lamivudine should cover the entire duration of chemotherapy and can be safely withdrawn in HBeAg negative patients with low pre-chemotherapy serum HBV DNA once recovery of

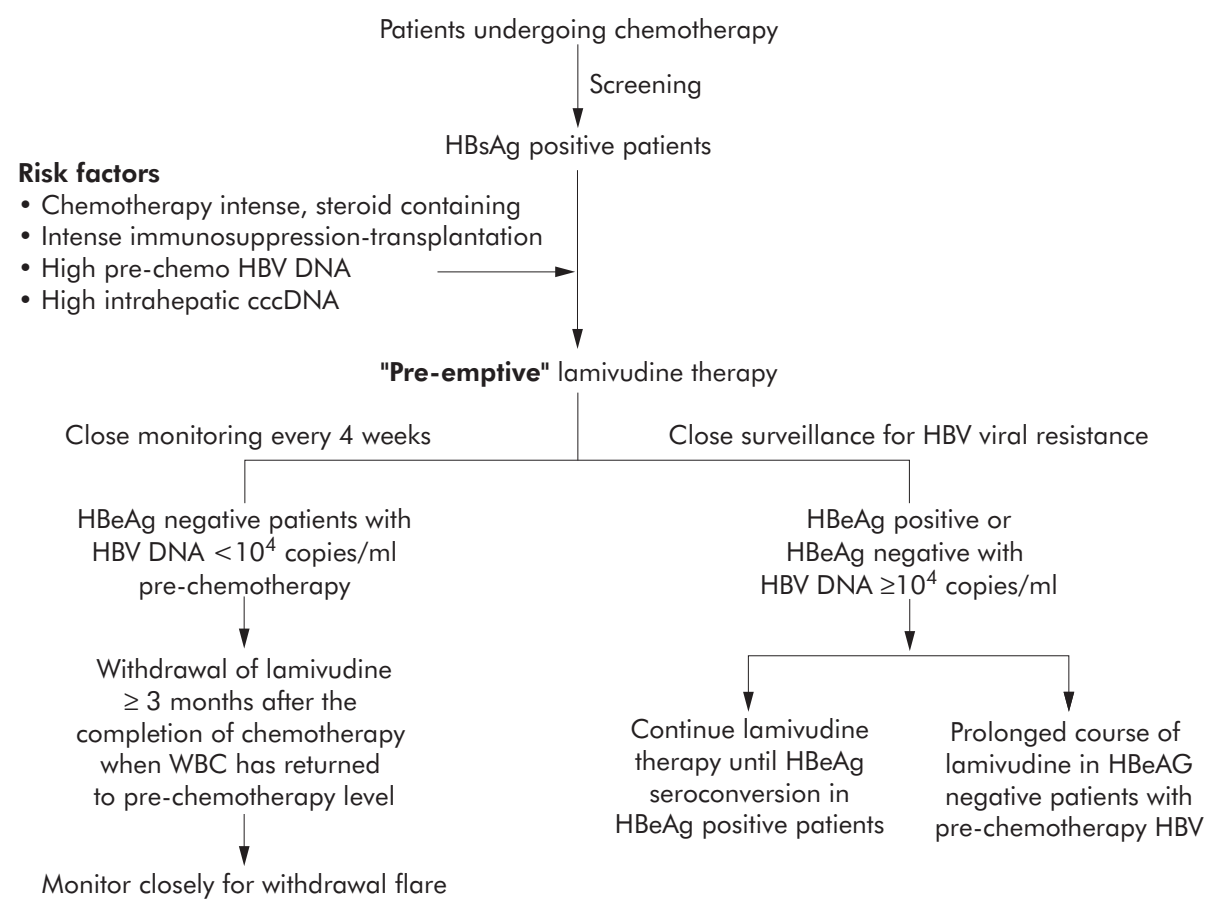

Figure 4 Algorithm for the management of patients undergoing chemotherapy in relation to hepatitis $B$ virus (HBV) reactivation. $H B s A g$, hepatitis $B$ surface antigen; $\mathrm{HBeAg}$, hepatitis $\mathrm{B}$ e antigen. 
white cell count has occurred. After withdrawal of preemptive lamivudine, we recommend close monitoring of their serum HBV DNA and aminotransaminase levels for evidence of withdrawal flare every four weeks for the first 12 months. Lamivudine should be resumed once a $1-\log _{10}$ increase in serum HBV DNA is detected. On the other hand, lamivudine should be continued until HBeAg seroconversion is achieved in HBeAg positive patients. Lamivudine should also be continued for a more long time in HBeAg negative patients with a pre-chemotherapy serum HBV DNA of $\geqslant 10^{4}$ copies $/ \mathrm{ml}$ (fig 4).

In conclusion, a high pre-chemotherapy serum HBV DNA is associated with an increased risk of HBV reactivation after withdrawal of pre-emptive lamivudine. The optimal duration of antiviral therapy may have to be prolonged in this subgroup of patients, even after completion of chemotherapy. Patients receiving pre-emptive chemotherapy should be closely monitored for a prolonged period of time as HBV reactivation leading to hepatic failure may still occur three months after withdrawal of pre-emptive lamivudine.

\section{Authors' affiliations}

C-K Hui, H-Y Zhang, Y-H Yueng, G K K Lau, Department of Medicine, and Centre for the Study of Liver Diseases, The University of Hong Kong, Hong Kong SAR, China

W W W Cheung, W-Y Au, A K W Lie, B C Y Wong, Y-L Kwong, R Liang, Department of Medicine, The University of Hong Kong, Hong Kong SAR, China

N Leung, Department of Medicine, Alice Ho Miu Ling Nethersole Hospital, New Territories, Hong Kong SAR, China

Conflict of interest: None declared.

\section{REFERENCES}

1 Liang R, Lau GK, Kwong YL. Chemotherapy and bone marrow transplantation for cancer patients who are also chronic hepatitis B carriers: a review of the problem. J Clin Oncol 1999:17:394-8.

2 Xunrong $L, A u, W Y$, Liang R, et al. Hepatitis B virus (HBV) reactivation after cytotoxic or immunosuppressive therapy therapy- pathogenesis and management. Rev Med Virol 2001;11:287-99

3 Hoofnagle JH, Dusheiko GM, Schafer DF, et al. Reactivation of chronic hepatitis B virus infection by cancer chemotherapy. Ann Intern Med 1982;96:446-9.

4 Perrillo RP. Acute flares in chronic hepatitis B: the natural and unnatural history of an immunologically mediated liver disease. Gastroenterology 2001; 120:1009-22.

5 Galbraith RM, Eddleston AL, Williams R, et al. Fulminating hepatic failure in leukemia and choriocarcinoma related to withdrawal of cytotoxic drug therapy. Lancet 1975;2:528-30.

6 Thung SN, Gerber MA, Klion F, et al. Massive hepatic necrosis after chemotherapy withdrawal in a hepatitis B carrier. Arch Intern Med 1985; 145:1313-14.

7 Bird GL, Smith H, Portmann B. Al. Acute liver decomnensation on withdrawal of cytotoxic and immunosuppressive therapy in hepatitis B carriers. Q J Med 1989;73:895-902.

8 Lok AS, Liang RH, Chiu KW, et al. Reactivation of hepatitis B virus replication in patients receiving cytotoxic therapy. Report of a prospective study. Gastroenterology 1991;100:182-8.

9 Nokamura Y, Motokura T, Fujita A, et al. Severe hepatitis related to chemotherapy in hepatitis $B$ virus carriers with hematologic malignancies. Survey in Japan 1987-1991. Cancer 1996:78:2210-15.

10 Yeo W, Chan PK, Zhong S, et al. Frequency of hepatitis B virus reactivation in cancer patients undergoing cytotoxic chemotherapy. A prospective study of 626 patients with identification of risk factors. J Med Virol 2000;62:299-307.

11 Coleman MP, Esteve J, Damiecki P, et al. Trends in cancer incidence and mortality, International Agency for Research on Cancer. Oxford, UK: Oxford University Press, 1993

12 Liaw YF, Leung N, Guan R, et al. Asian-Pacific consensus statement on the management of chronic hepatitis B: a 2005 update. Liver Int 2005;25:472-89.

13 Silvestri F, Ermacora A, Sperotto A, et al. Lamivudine allows completion of chemotherapy in lymphoma patients with hepatitis $B$ reactivation. Br J Haematol 2000; 108:394-6.

14 Matsuo K, Takenaka K, Shimomura H, et al. Lamivudine and glycyrrhizin for treatment of chemotherapy-induced hepatitis $B$ virus (HBV) hepatitis in a chronic HBV carrier with non-Hodgkin lymphoma. Leuk Lymphoma 2001;41:191-5.

15 Lau GK, He ML, Fong DY, et al. Preemptive use of lamivudine reduces hepatitis $B$ exacerbation after allogeneic hematopoietic stem cell transplantation. Hepatology 2002;36:702-9.
16 Lim LL, Wai CT, Lee YM, et al. Prophylactic lamivudine prevents hepatitis B reactivation in chemotherapy patients. Aliment Pharmacol Ther 2002; 16:1939-44

17 Shibolet O, llan Y, Gillis S, et al. Lamivudine therapy for prevention of immunosuppressive induced hepatitis $B$ virus reactivation in hepatitis $B$ surface antigen carriers. Blood 2002; 100:391-6.

18 Lau GK, Liang RH, Wu PC, et al. Use of famciclovir to prevent HBV reactivation in $\mathrm{HBsAg}$ positive recipients after allogeneic bone marrow transplantation. J Hepatol 1998;28:359-68.

19 Perrillo RP. Hepatitis B and renal transplantation: securing the sword of Damocles. Hepatology 2002;36:1041-5.

20 Yeo W, Chan PK, Ho WM, et al. Lamivudine for the prevention of hepatitis B virus reactivation in hepatitis $B$ s antigen seropositive cancer patients undergoing cytotoxic chemotherapy. J Clin Oncol 2004;22:927-34.

21 Lau GK, Yiu HH, Fong DY, et al. Early is superior to deferred preemptive lamivudine therapy for hepatitis B patients undergoing chemotherapy. Gastroenterology 2003;125:1742-9.

22 Keefe EB, Dieterich DT, Han SH, et al. A treatment algorithm for the management of chronic hepatitis B virus infection in the United States. Clin Gastroenterol Hepatol 2004;2:87-106.

23 Rossi G. Prophylaxis with lamivudine of hepatitis B virus reactivation in chronic $\mathrm{HBsAg}$ carriers with hemato-oncological neoplasias treated with chemotherapy. Leuk Lymphoma 2003;44:759-66.

24 ling R, Mutimer D, Ahmed N, et al. Selection of mutations in the hepatitis B virus polymerase during therapy of transplants recipients with lamivudine. Hepatology 1996;24:711-13.

25 Bartholomew MM, Jansen RW, Jeffers $\sqcup$, et al. Hepatitis B virus resistant to lamivudine given for recurrent infection after orthotopic liver transplantation. Lancet 1997;349:20-2.

26 Lai CL, Chien RN, Leung NW, et al. A one year trial of lamivudine for chronic hepatitis B. N Engl J Med 1998;339:61-8.

27 Persico M, De Marino F, Russo GD, et al. Efficacy of lamivudine to prevent hepatitis reactivation in hepatitis $B$ virus infected patients treated for nonHodgkin's lymphoma. Blood 2002;99:724-5.

28 Rossi G, Pelizzari A, Motta M, et al. Primary prophylaxis with lamivudine of hepatitis $B$ virus reactivation in chronic $\mathrm{HBsAg}$ carriers with lymphoid malignancies treated with chemotherapy. Br J Haematol 2001;1 15:58-62.

29 Hui CK, Sun J, Au WY, et al. Occult hepatitis B virus infection in hematopoietic stem cell donors in a hepatitis B virus endemic area. J Hepatol 2005;42:813-19.

30 Dai MS, Chao TY, Kao WY, et al. Delayed hepatitis B virus reactivation after cessation of preemptive lamivudine in lymphoma patients treated with rituximab plus CHOP. Ann Hematol 2004;83:769-74.

31 Leung N. Clinical experience with lamivudine. Semin Liver Dis 2002;22(suppl 1):15-21.

32 Liaw YF, Leung NW, Chang $\pi$, et al. Effects of extended lamivudine therapy in Asians patients with chronic hepatitis B. Gastroenterology 2000;1 19:172-80

33 Lau GK, Piratvisuth T, Luo KX, et al. Peginterferon alfa-2a (40 kD) (PEGASYS) monotherapy and in combination with lamivudine is more effective than lamivudine monotherapy in $\mathrm{HBeAg}$ positive chronic hepatitis $\mathrm{B}$ : results from from a large, multinational study. Hepatology 2004;40(suppl 1):171A.

34 Hoofnagle JH, Di Bisceglie AM. The treatment of viral hepatitis. N Engl J Med 1997;336:347-56

35 Dienstag JL, Cianciara J, Karayalcin S, et al. Durability of serologic response after lamivudine treatment of chronic hepatitis B. Hepatology 2003;37:748-55

36 Fung SK, Wong $F$, Hussain $M$, et al. Sustained response after a 2-year course of lamivudine treatment of hepatitis $B$ e antigen negative chronic hepatitis $B$. J Viral Hepat 2004; 11:432-8.

37 Peters MG, Singer G, Howard T, et al. Fulminant hepatic failure resulting from lamivudine resistant hepatitis $B$ virus in a renal transplant recipient: durable response after orthotopic liver transplantation on adefovir dipivoxil and hepatitis B immune globulin. Transplantation 1999;68:1912-14.

38 Mutimer D, Pillay D, Shields P, et al. Outcome of lamivudine resistant hepatitis $B$ virus infection in the liver transplant recipient. Gut 2000;46:107-13.

39 Colonno RJ, Rose R, Lewin SR, et al. Emergence of entecavir resistant hepatitis $B$ virus after one year of therapy in phase II and III studies is only observed in lamivudine refractory patients. Hepatology 2004;40:661A.

40 Shaw T, Locarnini S. Combination chemotherapy for hepatitis B virus: the final solution? Hepatology 2000;32:430-2.

41 Lok AS. Natural history and control of perinatally acquired hepatitis B virus infection. Dig Dis 1992;10:46-52.

42 Cahen DL, van Leeuwen DJ, ten Kate FJ, et al. Do serum ALT values reflect the inflammatory activity in the liver of patients with chronic viral hepatitis? Liver 1996;16:105-9.

43 Hui CK, Bowden S, Jackson K, et al. Clinical significance of intrahepatic hepatitis $B$ virus covalently closed circular DNA in chronic hepatitis B patients who received cytotoxic chemotherapy. Blood 2005;105:2616-17.

44 Lau GK, Leung YH, Fong DY, et al. High hepatitis B virus (HBV) DNA viral load as the most important risk factor for HBV reactivation in patients positive for $\mathrm{HBV}$ surface antigen undergoing autologous hematopoietic stem cell transplantation. Blood 2002;99:2324-30.

45 Cheng AL, Hsiung CA, Su IJ, et al. Steroid free chemotherapy decreases risk of hepatitis $B$ virus reactivation in HBV carriers with lymphoma. Hepatology 2003;37:1320-8

46 Yeo W, Zee B, Zhong $S$, et al. Comprehensive analysis of risk factors associating with hepatitis $B$ virus (HBV) reactivation in cancer patients undergoing cytotoxic chemotherapy. Br J Cancer 2004;90:1306-11. 